\title{
Chapter 11. Fataluku Forest Tenures and the Conis Santana National Park in East Timor
}

\section{Andrew McWilliam}

\section{Introduction ${ }^{1}$}

Fataluku society of Lautem, the most easterly district of East Timor, has attracted comparatively little detailed ethnographic research. 2 This paper aims to contribute to a better understanding of this region by exploring Fataluku customary tenures and cultural land management practices in the context of emergent land administration policy in East Timor. Fataluku land and forest tenures will be examined from a comparative perspective, placing them within the wider context of eastern Indonesian ethnology.

The district of Lautem contains one of the finest contiguous blocks of dense lowland tropical and monsoon forest on the island of Timor. Covering an area of some 300 square kilometres and incorporating the heavily forested Paichao Range of low mountains (to 925m), this forest zone extends from the eastern extremity of East Timor (Jaco Island) in a narrow band (7-10km) westwards following the unpopulated southern coastal hinterland. As a region with great ecological value and complex biodiversity, the area has long been accorded special significance. ${ }^{3}$ During the period of Indonesian rule in East Timor (1975-99), much of the forested zone was classified as a natural conservation reserve (kawasan suaka alam). ${ }^{4}$ This category of protection, on paper at least, prohibited logging and other forms of extractive activity within its boundaries. Subsequently, under the United Nations Transitional Administration in East Timor (UNTAET) from 1999, after the truculent withdrawal of Indonesian forces, the area was reclassified and declared one of 15 so-called 'Protected Wild Areas' (UNTAET Reg. 19/2000). This sentiment and commitment to recognize and conserve the heritage and resources of the Tutuala-Paichao Reserve has continued under the new government of the independent East Timor. In 2002, through its Directorate of Forestry, the Government initiated a program to formally demarcate and legislate the area as the country's first 'National Park'.

As part of this program of development, the East Timorese Administration has formalised a memorandum of agreement with the NSW National Parks and Wildlife Service (Australia) to collaborate in developing effective park management strategies and resource inventories. Although conservation is the primary objective in the establishment of the park, this does not preclude 
complementary development possibilities including eco-tourism, bio-exploration and/or carbon credit trading. 5

The concept of the park also serves other government agendas, especially the broader 'nation-building' task of post-conflict East Timor. A recent proposal to name the park 'The Conis Santana National Park' honours the sacrifice of a former, highly revered Falantil commander (1993-98), and thus commemorates the nationalist struggle for independence from Indonesian and Portuguese colonial rule. The fact that the forested region of the proposed park provided shelter and refuge over many years for armed Falantil guerillas, including then resistance leader, Xanana Gusmao, gives the region a special standing in the history of East Timor

Without denying the importance of these sentiments and values and the evident enthusiasm in government for its formal creation, the prospects for the successful establishment of the park and the development of effective management regimes are highly dependent on the future regulatory framework and ownership status of the region. This issue arises because, contrary to perceptions of a would-be wilderness of natural heritage values, the greater part of the forested zone in this proposal is not composed of ancient old-growth primary forest. Rather, the forest reflects a highly enculturated mosaic of aged and long-fallowed secondary regrowth of former swidden gardens and settlement sites. Its very existence as a canopy forest is, to a significant degree, the result of a particular history of disengagement by local 'traditional owners' due to coercive external pressures applied by successive colonial governments, especially in the form of resettlement policies and restrictive security arrangements. Although long ignored and subsumed within government regulations, customary tenures and local claims of Fataluku-speaking populations to the forestry zone remain substantially intact. They form the historically asserted and contested grounds on which any negotiation and determination of land title and management authority within the forested park would seem to rest.

As a result of preliminary consultations with selected community leaders, government forestry staff informally acknowledge the existence of a right to 'traditional land' (BI: tanah adat) and interests to the resources of the park area. They accept the need to incorporate continuing low-level extractive activities undertaken by customary users into the park management policy. However, there is no consensus or agreement, at this stage, over the prospective formal status of their practical interests and ownership claims. Nor has there been any sustained attempt to systematically investigate the ethnographic context within which these claims emerge.

This paper offers a preliminary contribution to that exercise and explores elements of continuing Fataluku customary attachments and affiliation to the proposed national park. What emerges from these insights is a forest environment 
inscribed with complex and layered social meanings and memories. Local forest tenures are constituted and embedded as much in the sacred geographies and spiritual connections that people retain with specific localities, as they are in the histories of personal engagement with and economic exploitation of the forest environment. The proposed national park is, for many Fataluku groups, a wholly local preserve and the vital inheritance of their ancestors. In this context, nationalist and public claims for control and 'management' of the forest tend to be viewed with a mixture of scepticism and mistrust by local groups with a landed interest in the outcome.

\section{Locating Fataluku}

The indigenous Fataluku-speaking population of East Timor, currently numbering about 35,000 speakers, forms the largest linguistic community of Lautem district. Lautem itself is composed of five subdistricts (posto) and Fataluku speakers form the dominant population group in the three most easterly areas (Tutuala, Fuiloro and Lautem). ${ }^{6}$ Among Fataluku native speakers there are numerous dialect forms, reportedly up to seven varieties, which are nevertheless mutually intelligible. The term Fataluku can be translated as 'plain' or 'straight' speech. Although the Tutuala dialect in the eastern extremity of the region is generally considered to express the purest form of the language, the most popular and widely spoken version of Fataluku centres on the district capital, Los Palos, and the more populous central subdistrict of Fuiloro. ${ }^{7}$

Fataluku is one of the principal non-Austronesian languages of East Timor classified as part of the Trans-New Guinea phylum with strong West Papuan substratum features (see Hull 1998: 22). ${ }^{8}$ While linguistic differences distinguish Fataluku populations from their more numerous Austronesian-speaking neighbours in East Timor, it is by no means obvious that the different phylogenetic origins of Fataluku as a language have produced a corresponding degree of cultural distinction (see Bellwood et al. 1995: 3-4). As Hull has observed, Fataluku society reflects a hybrid cultural identity, being more 'Proto-Malay than Melanesian in racial type' and possessing the 'most typical Austronesian material culture in Timor' (1998: 165). ${ }^{9}$ In this regard, the existence of a remnant Austronesian linguistic island of Lovaia or Makwa 10 within the dominant Fataluku language area suggests a long-term engagement with Austronesian social and cultural ideas and practices, however these might be defined.

A predominantly agrarian society, Fataluku people have for centuries pursued systems of smallholder dry-land swidden agriculture combined with irrigated rice production in favourable areas, as well as extensive systems of animal husbandry focused on buffalo, domesticated pigs and goats. Hunting in the forests and coastal margins is also undertaken regularly and most of the 
population relies on a wide variety of forest products for domestic and household use.

At the present time, settlements in Lautem tend to form concentrated residential groupings and linear developments along arterial roads. Residential populations are grouped administratively into villages (suco), ${ }^{11}$ a legacy of Portuguese colonialism, and usually contain a varied number of constituent hamlet (aldeia) settlements within the wider land area of the village. These patterns of settlement, however, are, for the most part, comparatively new. By and large, they reflect the policies of successive Portuguese and Indonesian administrations to concentrate and spatially contain Fataluku sociality in the interests of facilitating administration and control. More traditional patterns of residence were dispersed. People tended to live in small clusters of family based households $(\mathrm{otu})$ in swidden gardens, moving with the rhythm of forest clearing and fallow, and affiliating to one or another larger settlement and ritual centres known as lata.

\section{Origins and Inscriptions of Place}

One of the first comments I recorded in my investigations into Fataluku land tenure was that all the land had long been divided among the respective resident and named ratu, which comprise key social institutions in Fataluku society. Subsequent enquiries identified dozens of named ratu groups historically resident within Lautem, the names often recurring in different localities. It is at the level of the patrifilial ratu that forms of communal or common property ownership to clearly defined blocks of arable land are asserted and organised. Evidently the evolution of these patterns of customary land tenure are the result of complex historical engagements between congeries of ratu defined variously as allies and enemies, and their mutual interaction with external, colonising powers. At the present time borders between ratu lands remain clearly demarcated, although not recognised officially by government. Nevertheless, across Lautem, there is apparently no land to which authoritative customary claims of tenure do not apply.

The name 'ratu' for the key social institution of Fataluku society is an example of the thoroughgoing Austronesian influences on the cultural patterning of social practice and formation. The term means 'ruler' or 'lordly', and its cognates, datu, dato and datuk, are familiar status terms in Austronesian-speaking contexts. Membership of a ratu group in Lautem consists of a core of male kinsmen, their in-married spouses, and children from these marriages. Although in the past it is likely that individual ratu formed close-knit, largely co-residential and localised groupings, over time membership has dispersed across Lautem and regions beyond. Nevertheless, the unity of the ratu, its shared and emplaced ancestral origins, spiritual and ritual obligations, and the areas of land to which it lays claim, represent a key set of values reproduced over time. Social and personal 
identities of individuals are intimately connected and reproduced through the discursive frames of ratu ritual practices and relation. These markers of affiliation are expressed in a variety of ways; from the use of certain inherited indigenous names, ${ }^{12}$ ritual knowledge and practice, ${ }^{13}$ to ratu-specific textile designs, and inherited animal ownership brands and food proscriptions. Normative social relationships are formulated around continuing and complex systems of exchange and marriage alliance between the exogamous ratu affiliations.

Within this broad pattern of social organisation, Fataluku distinguish a series of clearly defined class or caste-like divisions which have been reproduced over many generations. ${ }^{14}$ Ratu identity is accorded the senior, classificatory 'elder sibling' status (kaka) and appears to include a majority of the population. A junior and socially subordinate grouping, referred to as paca, is accorded a 'younger sibling' status (noko). Paca groups form an integral part of the wider ratu social collectivity, their status linked to social differentiation in the mythic past. A third group of people are known as akanu and are defined as descendants of former slaves and war captives. Akanu are aligned notionally with different ratu groups but their ascribed social status is weak and their rights limited and constrained. By definition, they are severed from their origins and therefore maintain no direct connection with their ancestral land. Intermarriage between the social levels was uncommon traditionally and, although the divisions carry less weight in contemporary politics and society than before, tensions between the social levels are still evident especially in relation to contracting marriage. ${ }^{15}$ For the purposes of this discussion, however, it is sufficient to know that all land is traditionally vested in the ratu, and there are no higher order structures of customary landownership. Within the ratu jurisdiction, rights to parcels of land follow the segmentary houses of classificatory siblings, with overall authority in land matters vested in the senior male agnates of the ratu.

The historical division of Fataluku lands and the development of common property regimes over specific areas are constituted in and through ancestral histories and itineraries. Careful and privileged preservation of narratives of origin (nololo, sau) are combined with continuing practices of sacrificial communication with ancestor spirits that link individual members of the ratu with sites of ancestral origin. Although there appears to be wide variation in the specificities of cultural and ritual practice between different Fataluku ratu groups, a number of common sites for sacrificial communication and commensality can be discerned. All are designated as sacred or taboo (tei) and for that reason must be approached with caution and respect.

Four principal categories of 'sacred places' (lata teino) are recognised. They comprise a network of interlinked sites for members of the agnatic kin group. Every ratu group recognises a calu ia mari ('ancestor footfall/footprint') site, located at different points along the coast, which represents the mythic landing 
place of the original ancestor/s of the group. Customarily, ia mari sites are marked by an altar post (sarapua) erected on a base of flat stones in the characteristic and iconic image of sacrificial sites in Timor and elsewhere in the eastern Indonesian Archipelago. 16

A second focal site of sacrifice is referred to as ete uru ha' (heartwood). These places are marked conventionally by two carved figurines of a man and a woman. They represent the first ancestral couple and often, simultaneously, the site of the first settlement of the group. ${ }^{17}$ They are said to guard the path of ancestors and are placed facing the direction of their origins.

Complementing the sites of ancestral arrival and origin are a variety of massive stone graves (calu lutur tei) that contain ancestral remains. Typically these are situated within the former walled settlement sites (lata paru) that are found in large numbers throughout the region. ${ }^{18}$ Often located in strategic defensive positions on hilltops and cliffs, lata paru and their ancestral graves represent important sites for worship and sacrifice by members of a ratu experiencing difficulties and seeking guidance or relief from severe chronic illness, barren marriages and other challenges.

The fourth main component of this complex of cultural belief and practice is house altars and sacrificial shrines (aca kaka) ${ }^{19}$ that are maintained to provide protection and spiritual assistance for constituent households of the ratu. Each shrine contains a stone hearth (aca pata) and a small forked post (sikua-from the sikua tree [Bridelia ovata]), ${ }^{20}$ which serves to mediate communication with the ancestors. Ideally, married male members of the ratu maintain a separate aca kaka in their newly created households. These days, however, it is more typical for ratu house segments to utilise one central shrine that serves as the focus for extended household rituals. Sacrificial household rituals are directed to lineage ancestors. ${ }^{21}$ They are conducted for all manner of life-cycle transitions and as a source of spiritual protection for the health and wellbeing of its members. ${ }^{22}$ Rituals typically involve the sacrifice of domestic animals, 'feeding' (fané) the ancestors with offerings of offal and rice, and the shared consumption of the 'sacred meat' (leura tei) among male kinsmen within a ratu segment. ${ }^{23}$ The use of auguries (ari toto) and divination (lonia, mu'ufuka totole) to determine the efficacy and messages conveyed through rituals are also common features of Fataluku sacrifice and collective knowledge.

Despite the high levels of avowed Catholicism and the depredations of Indonesian rule of Lautem for many years, indigenous religious belief and ritual practice remains fundamentally important in Fataluku social life. Close attention to ancestral obligations and fear of the consequences of their neglect condition the rhythm of social life and link domestic rituals with the sacred landscape of ancestral origins across the region. 


\section{Forests, Settlements and Dislocation}

The historical vesting of ownership in land by a particular ratu group is denoted by the title mua ho cawaru, which may be translated as 'lord of the land'. In more formal language, the parallel phrase is: Mua cao vele ocawa :: horo cao vele ocawa (land head skin lord :: gravel head skin lord). ${ }^{24}$ This phrase speaks to the Fataluku idea of a conceptual distinction between the 'body' of the earth and its 'skin' (vele), which is cultivated for staple food crops. The title of 'lord of the land', held by a particular ratu group in relation to a defined area of land, is one that confirms and honours their status as founder settlers. Their claims to precedence of origin provide the cultural basis for asserting ownership over tracts of land within their ancestrally defined jurisdiction. Their status is also maintained through their ritual custodianship of spirit forces and entities associated with particular territories (part of the pre-existing tei sphere).

Ideally, the communally inherited land of the ratu may not be sold or alienated. It forms part of the 'sacred land and sacred garden' of the group (mua tei ho pala tei). ${ }^{25}$ However, marriage and long-term alliance relationships between ratu groups moderate this perspective. Alliance allows for complex sharing arrangements concerning forested swidden garden land that may be sustained over many generations. Fataluku designate marriage alliance relationships with the terms arahopata and tupurrmoko. These metaphors encode a cultural and status asymmetry between affines. The arahopata, the 'base and post', represent the symbolically 'male' wife-givers and are contrasted with their symbolically 'female' wife-takers, or tupurrmoko or 'little women'. Under Indonesian rule, when many populations were relocated and restricted to cultivating defined areas, practices of temporary use rights to ratu land also developed. These people as newcomers are said to be 'passengers' (micani horune) on the land of resident ratu, with limited rights of cultivation for seasonal food crops but without claims to ownership or inheritance.

Preliminary explorations of the forested zone with local claimants to traditional land have revealed something of the scope and character of continuing traditional tenures within the proposed national park. I present them here as two case studies. To my knowledge, there has never been any sustained attempt to map ratu clan land boundaries in Lautem. Their status was formally ignored within state-based administrative regimes of the Indonesian Government and the Portuguese before them. ${ }^{26}$ As a result, traditional titles to land reside for the most part in the minds and narrative memories of ratu elders, but they are no less significant or important to the integrity and reputation of the ratu for this.

The first case study is based on several days' walking in the dense undulating forest around the western foothills of the Paichao Range. The second explores something of the indigenous attachment to land in the Vero River Valley, which 
lies to the south of the settlement area of Tutuala and drains into the sea to the east of the Paichao Range (see Map 1). The studies illustrate both the reality of population displacement from these areas and the continuing reproduction of symbolic and practical attachment to ancestral country.

\section{Map 1: Lautem showing approximate location of the conservation zone}

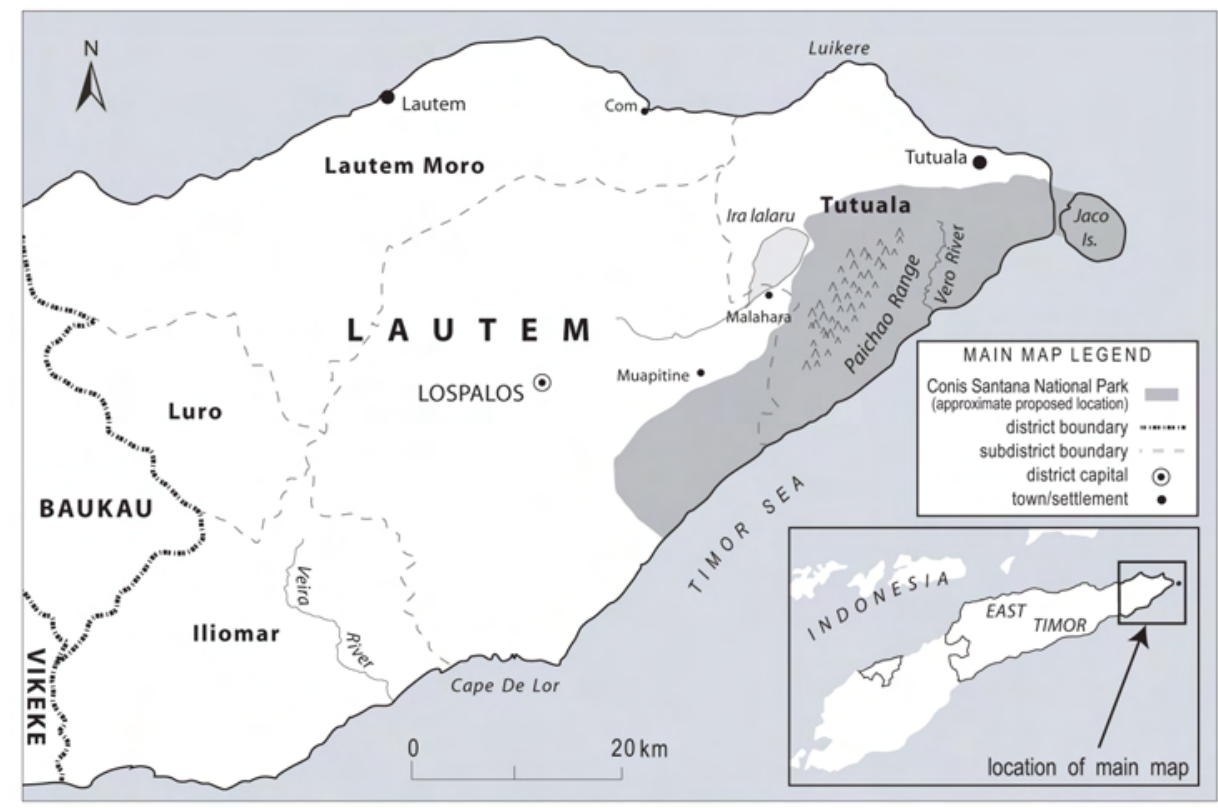

\section{Perspectives from the Paichao Range}

Contemporary members of the patrifilial Paichao ratu group currently reside in the hamlet (aldeia) of Malahara, located on the southern shores of the shallow lake, Ira Lalaru. The forested mountains of the Paichao Range border to the south and extend east in a series of forested peaks. The residents of Malahara cultivate the adjacent hillsides with seasonal maize, cassava and secondary food crops. Malahara comprises one of the constituent communities of the village (suco) of Muapitine.

Formerly, the Paichao ratu community lived in and around their historical forest settlement, Veteru (lata paru), some $6 \mathrm{~km}$ to the south towards the coast. Historically, Veteru formed a distinct administrative hamlet in the village of Muapitine. After the Indonesian occupation of East Timor in 1975, the community of 36 households fled and dispersed, with a small group eventually being resettled in Malahara on land owned by Ponu Ratu. ${ }^{27}$ They still live in the settlement but their numbers have dwindled to six households. Nevertheless, they still hope to return home to cultivate their own land if their numbers increase, as 
their present circumstances preclude inheritance of land cultivated by permission from Ponu Ratu.

I was invited to join a senior member of the ratu and his nephew in visiting ancestral origin sites of Paichao ratu, prompted by their concerns over the proposed establishment of the national park and the uncertainty of future tenure arrangements. With sufficient food and camping supplies, our party of three plus hunting dog left Malahara and followed a track into the nearby forest, passing through a complex of fallowed swidden fields and secure timber garden fences. Entering the forest proper, my guide, Umberto Rakupua, left the path and picked out his own track through the dank undergrowth littered with coralline rubble, negotiating the dense undulating forest terrain with consummate and barefooted ease. Walking under closed canopy forest, my companions pointed out a diverse range of tree species and vines, along with their various practical uses for building, consumption and medicinal purposes. We passed through extensive areas of lowland forest with networks of remnant limestone garden walls and sites of former habitation. As distinctive cultural markers, these intersecting walls provided objective historical evidence of former occupation and land claims; all associated with former members of the Paichao ratu community, according to my guides.

By the late afternoon, in light rain, we reached the first of three historical settlement sites (lata paru) located at high points in the forest and characterised by distinctive and substantial stone-walled fortifications with strategically guarded entrance ways. Although long abandoned as a settlement site, possibly for more than 100 years, the social history of the lata paru of Pariloho ratu (or one version of it) was quite familiar to my guides. According to this view, Pariloho ratu had been granted permission from the original landowner, Paichao ratu, to settle temporarily in the area. Over time, relations had soured between the two groups and Pariloho ratu was pushed out and forced to seek a new settlement site outside the region. Although a number of old graves remain untended in the defensive walled complex, members of the Pariloho ratu are not known to return for ceremonial activities, and the Paichao ratu group has reasserted its ownership over the area.

As night fell, we camped in a spacious limestone rock shelter on the eastern face of the old settlement, a site used by former Falantil and Indonesian Army troops alike. The next morning we walked for another three hours through the forest to the principal origin site for Paichao ratu. Further numerous useful tree and plant species were identified, 28 including a massive Pua ara forest tree, which for generations has housed 'honey-bee hives' (wani le: lit. 'bee house') with their white wax head (ucu pacu) structures hanging off the upper branches. ${ }^{29}$ Beeswax was formerly a lucrative commodity sold by the kilo and recognised as ratu property. 30 
By midday, we arrived at the massive elongated limestone outcrop of Veteru, heavily overgrown with large fig trees (hama) and tangled vines, and barricaded with metre-wide limestone walls. Culturally, Veteru is understood to be a fossilised seagoing stone boat (loiasu matar), which carried the Paichao ratu ancestors to Timor and lodged in the foothills of the Paichao Range. It is oriented on an east-west axis, with the head ( $\mathrm{cao}$ ) of the boat to the east and the tail ( $\mathrm{rik}$ ) to the west. The centrepiece of the lata paru complex is a large double stone grave believed to be that of the first Paichao ratu ancestor and his wife (a woman from Tutuala). Cleaned of invading vegetation, the grave is oriented with its headstone to the east towards the mountain of Paichao (Paichao ili). It forms the key sacrificial site for the group in times of illness and misfortune.

At the time of the Indonesian Army invasion of East Timor in 1975, the Paichao ratu and their resident affines (vaianu) lived in scattered households around the base of Veteru, then classed as an administrative povoção (hamlet) by the Portuguese Colonial Government. Remnant areca and coconut palms still grow scattered among the rubble of abandoned swidden garden walls, but otherwise secondary forest regrowth has obliterated most evidence of prior settlement.

From this vantage point, the forest land of Paichao ratu extends in all directions. To the west is the River Karo'o, the boundary with Reme Latu Loho ratu, whose contemporary members now live in the main settlement of Muapitine near Malahara. ${ }^{31}$ To the east is the boundary known as Vekase Vero'o, the border of Tutuala lands and the senior patrifilial owner, Renu Ratu (see following case study). Formerly, on Mt Paichao itself were the traditional lands of another group, Huamai ratu. Their members are said to have all died out and their lands remain unclaimed to the present.

Little more than 500 metres to the west of Veteru on a ridge overlooking a steep slope to the forested stone country of the coastal lowlands lies another abandoned lata paru. Known by the placename Lamira, the old fort was formerly occupied by an allied group known as Kanaluri paca. According to oral tradition, this group fell into enmity with their western neighbours, Reme Latu Loho ratu, from the lata paru Voviara. In the murderous hostilities that ensued, Paichao ratu went to the aid of Kanaluri Paca, but lost two of its members in the fighting. The survivors of the settlement, unable to pay the compensation demanded for the deaths of their allies, agreed to abandon their site and gift their lands to Paichao ratu as payment. They subsequently sought refuge with Serelau ratu on lands near Lake Ira Lalaru where their descendants live today.

From the crumbling ruins of Lamia, our party continued west and then north on a circuitous return route to Malahara. At a certain point, we joined a major footpath that links Malahara to the beach, Vaiara, on the southern coast. This site provides the location for the annual gathering of sea-worms (meci; Eunice 
virides), which assemble in massive numbers in late February and early March. All households from Malahara reportedly make the trek to the beach on the appointed full moon for this ceremonial harvest of the sea's bounty (see McWilliam 2003).

\section{Perspectives from the Vero River Valley}

The upper reaches of the Vero River lie close to the contemporary settlement area of Tutuala. The single constituent village (suco) of Pitilete comprises four hamlets (aldeia), namely Pitilete, Cailoro, Iyoro and Vero. Extensive areas of dry monsoon forest and fallow swidden gardens surround the settlements, which are located about $400 \mathrm{~m}$ above the coast with commanding views over the surrounding seas. For the most part, the location of current settlements is an artefact of recent colonial history reflecting, in particular, the dictates of the Indonesian Government and its policy of containing Fataluku populations in closely supervised proximity. This included former residents of the Vero Valley, who were forced to relinquish their swidden fields and tree crops in the lowland forests in favour of concentrated settlements adjacent to the sealed road. Here, their movements were restricted and monitored closely by local government staff and military commanders.

The small hamlet of Vero is a case in point. Staunch supporters of the resistance struggle and the Falantil guerillas who continued a cat and mouse insurgency in the surrounding forests for more than 20 years, most of the households of the hamlet had little opportunity to maintain their swidden gardens on ancestral lands. ${ }^{32}$ During this period they gained access and cultivation rights to nearby garden lands from allied local ratu groups, usually strengthened through marriage alliances and the lifelong reciprocal obligations that characterise these relationships. With the achievement of independence, however, residents of Vero are once again considering the possibility of returning to their ancestral country and re-establishing their attachments to the area. ${ }^{33}$ While not opposed to the idea of a national park that would incorporate their lands within a conservation zone, many have expressed concern over the future of their inherited rights or resource use and ownership under a new management regime.

My visit to the valley and subsequent insights into its cultural landscape was facilitated by the political leader of Vero hamlet and a patrifilial member of Serelau ratu that maintains entitlements in the Aleara Lafae area of the Vero River Valley. A kilometre or so from the main Vero settlement, Mario dos Santos Loyola cultivates a block of dry-land swidden maize garden with members of his extended family. ${ }^{34}$ The southern garden fence marks the contemporary edge of cultivated land and it was from here that we entered the forest proper and joined the well-trodden path that leads down through the hills to the coast. At this point the mouth of the Vero River lies some six kilometres to the 
south-east, with the dense coastal forest rising into the Paichao mountain range extending into the western distance.

Though evidently drier than the forests of the western Paichao Range, the path descends through dense-canopy forest, broken occasionally with patches of open grassy knolls and fields. In the upper reaches, evidence of former cultivation is less apparent and lends credence to Mario's claim that there remain extensive areas of old growth-forest. ${ }^{35}$ Along the way, he pointed out numerous plant species used for traditional medicine and remedies that people continue to rely on in the absence of alternatives. Like many of his kinsmen, Mario has spent periods of time living in the forests and has a keen eye for edible plants, fruits and leaves. One specimen he described as 'presidential food', the leaves of which, eaten raw with fresh coconut, were a preferred forest food of former guerilla leader Xanana Gusmao, during his days secreted in the area.

Although the specifics of Fataluku land and forest tenures to the Vero River Valley require further research and articulation, a general consensus of the broad outline is readily accepted. In this view, the mythic original immigrant settlers of the area arrived in seagoing boats (loiasu) at the mouth of the river. At this location is an ia mari tuliya (ancestral footprint) commemorative site known as Telu'o. ${ }^{36}$ Collective sacrificial ceremonies are regularly undertaken at this location, which also still forms the focus for the annual sea-worm (meci) gathering festivals among contemporary descendants affiliated with the site.

The origin ancestors to the area are referred to as two named pairs of ratu: Renu/Paiuru and Marapaki/Keveresi. Mythically, they are distinguished from the time of their ancestral maritime arrivals. After a period of intense feuding, they are said to have divided the land along a common border following the Vero River inland. Over time, other immigrant boats arrived and sought rights of settlement from these founder groups. The subsequent history of the Vero Valley, including its population dynamics, the impact of warfare and marriage alliance has seen the land become consolidated under the authority of a range of ratu groups with defined boundaries and claims, all lying within the historical administrative jurisdiction of Suco Pitilete.

West of the Vero River and extending to the border (Vekase Vero, Ili Mimiraka) ${ }^{37}$ with Paichao ratu mentioned earlier, all groups agree that Renu ratu is the senior authority. ${ }^{38}$ Renu ratu is referred to as the nalu lafae, the 'great mother', by virtue of the continuing marriage of its daughters to in-marrying settler ratu groups (tupurrmoko). This accords them a 'progenitor' status for subsidiary groups that maintain received and nested rights to land in this process. In other words, Renu ratu maintains the status of a wife- and life-giving group (arahopata: 'base and post') in relation to their subsidiary allies (tupurrmoko). These allies include members of Paiuru ratu, Pae Lopo ratu, Aca Cao ratu, Pai ratu, Tana ratu and Serelau ratu among others, all of whom were 
allocated settlement rights in the forested hinterland of the western Vero River Valley and maintain connections to former settlements and grave sites in the area. 39

In the present day, these ancestrally constituted relationships are recalled and reproduced in continuing alliance relationships between descendants of the founding ancestors. Although long displaced from the forested Vero Valley, members of these ratu maintain a vital link to their origins in the narrative histories and emplaced mythologies of settlement, made manifest in the sacred geography of the land. The former fort (pamakolo) and barricaded settlement (a lata paru named Haka Paku Leki) of Renu ratu, situated midway between the sea and the upper reaches of the Paichao Range, is a case in point. Along with the ritual landing site of Telu'o, the former settlement with its ancestral graves provides a key site for the sacrificial enactment of attachment by members of the Renu ratu group. Allied ratu maintain their own sacrificial and culturally significant sites in the area. They include the identification of the mythic 'fossilised' boats of immigrant ancestors across the valley, numerous abandoned walled settlement sites (lata paru) and aged cultivars such as coconut and lontar palms, which mark earlier swidden gardens. Upstream from the mouth of the Vero River is the 'stone boat' of Marapaki, standing in an area of grassy flats and covered with a tangle of vegetation. Nearby, I was shown the imprint of the 'boat' of Serelao ratu, a shallow elongated dry waterhole, marked by a sacrificial post (ete uruha'a) where the ancestral boat was said to have rested before moving higher up to its current position at Alaera Lafae. The subsequent move was prompted, reportedly, because of its overly close proximity to the 'boat' of Marapaki. Nevertheless, the site remains a defined location for ritual sacrifice and prayer among members of the ratu owning group. Like its mythic counterparts emplaced across the cultural landscape of the lower Vero, the imprint of the ancestors attests to the continuing cultural connections that contemporary Fataluku people maintain with this area, lying deep within the proposed boundaries of the national park.

For all the intense connections to the lower Vero, however, the forested landscape remains 'unsettled' and generally uncultivated, a condition thatappears to have existed for about 50 years since the end of Japanese wartime occupation in 1945 and the reinstatement of Portuguese colonial rule in East Timor. According to local memories, this period saw the displacement, relocation and concentration of Vero Valley farming communities north to the main settlement area of Tututala. Before 1945, the population of the Vero community in the forest is said to have numbered more than 150 households dispersed along the coastal hinterland, and was seeking to be recognised as an autonomous village (suco) in its own right. The depredations of World War II, and the postwar history of East Timor, meant that the population of Vero community suffered demographic decline and still remains less than one-third of its earlier size. 
Despite this displacement of the former settled population, the proximity of contemporary settlements in Tututala means that there remains a continuing and comparatively intensive utilisation of resources. Timber and rattan vines, as well as medicinal trees and plants are gathered, and hunting for a wide range of species is undertaken regularly. The use of spears (choro), hunting dogs (iparu), traps and blow-pipes (tutufa) represent the main hunting implements. Favoured forest species include monkeys (lua), deer (vaca), marsupial cuscus (acuru, lo), feral pigs (pai hoto) and bats (maca), along with a range of bird species (olo), freshwater fish (api), prawns, lizards and snakes. All provide a rich and varied supplement to rural diets. In the lower Vero River Valley, I was introduced to my guide's father's younger brother (kin term: Palu noko). At the time, he and his wife were busy curing fleshy strips of a large sea turtle (ipitu), which he had caught on the beach and was intending to take back to the settlement for consumption and sale. ${ }^{40}$

The importance of forest fauna is also highlighted in ceremonial practices associated with the dry-season cultivation of maize gardens and associated food crops, the so-called temuru pala ('eastern gardens'; cultivated from June to early September). As part of the ritual management of cropping and the successful gathering of an abundant yield, maize harvest rituals (cele sakawahine, cele masule and cele sipile) are accompanied by the hunting and shared consumption of 'forest meat' along with quantities of locally produced sugar-palm wine (tua piti) and spirits (tua haraki). The collective nature of harvesting with participating family groups means that a significant 'harvesting' of local forest species occurs at this time and undoubtedly contributes substantially to rural diets as well as periodic pressures on forest fauna.

For the resident populations of Tututala with ancestral links and attachments to the Vero and Paichao Ranges, the forest and its resources represent a region of abiding socioeconomic value. Simultaneously, an 'archive of past habitation and sociality' (Fairhead and Leach 1996: 113) and 'landscape of memory' (Hviding and Bayliss-Smith 2000), the forests also form a complex ecological arena for practical resource exploitation and a rich store of arable land, which may yet be brought back into production in the future. Although its potential value as a conservation area of national importance and the location for eco-tourism or bio-research might be appreciated and understood, it is by no means obvious to local Fataluku that these prospects will prove to be consistent with local interests and inherited rights.

\section{On Fataluku Customary Tenures and Forest Management}

The proposal to develop a national conservation park in East Timor, the first in the context of national independence, has created the requirement for a better understanding of customary Fataluku land tenures within the forest reserve. This paper has highlighted something of the emplaced significance of Fataluku 
customary attachments to the area and the structure of social relationships within which land tenures are embedded. Further research and cultural mapping will undoubtedly provide a more detailed perspective on the complex networks of engagement with the forested landscape. ${ }^{41}$ Arguably, such studies are critical to the development of strategic approaches to effective park management and a more informed basis for negotiating management agreements. Nevertheless, these preliminary observations are perhaps sufficient to indicate something of the character of Fataluku attachments to ancestral lands; attachments that appear to have much in common with neighbouring ethno-linguistic groups in the wider region. These attachments also highlight something of the complexity of and challenges for incorporating customary tenure regimes within national land administration structures.

The comparative ethnography of eastern Indonesia, and particularly the Lesser Sunda Islands of which East Timor is a constituent part, has focused on the predominantly Austronesian-speaking language communities of the region. Many of these studies have highlighted a range of common cultural features and conceptions about locality and landscape that are thought to reflect aspects of a shared Austronesian heritage (see Fox 1997; Fox and Sather 1996; Bellwood, Fox and Tryon 1995; Atkinson and Errington 1990). These shared characteristics are varied and numerous but may be thought to minimally include the following aspects. Firstly, there is an attention to the valorising of space through symbolic coordinates. Two axis systems are prominent in eastern Indonesia, whereby the primary orientation follows the east-west axis with a secondary orientation utilising an upstream-downstream, or right-left axis. Secondly, there is a common indigenous focus on 'discourses of origin' and the relative precedence of origins as a basis for structuring social relations. This orientation to the past is expressed frequently through the reproduction of narrative topogenies (discourses of place) for the encoding of social memory in cultural landscapes. ${ }^{42}$ All these societies have also been demonstrated to share an abiding interest in the representation of relationships and processes by paired metaphors of complementarity and difference. Social meanings are constructed culturally through such 'symbolic operators' as trunk and tip, male and female, elder and younger, right and left, hot and cold. Typically, too, these culturally significant asymmetric categories are applied recursively and thus generate orders of difference or precedence within social contexts. These combinations of elements, applied creatively, have been shown to be highly illustrative of the dynamic and often contested relationships characteristic of eastern Indonesian and wider Austronesian societies (see Fox and Sather 1996; Vischer forthcoming).

Although clearly of non-Austronesian linguistic origins, the schematic outline of Fataluku land and forest tenures presented in this paper appears to share many of these characteristics of Austronesian ideas of place and landscape. The principal coordinate of orientation among Fataluku is ordered along the east-west 
axis. Typically this is expressed as an associated distinction between head and tail: mua cao, mua ulafuka 'head of the land, tail of the land'. A second-order orientation is marked in relation to the seas to the north and south. The terms tahi tupurru - tahi calu ('female' sea - 'male' sea) represent a composite linguistic construction of Austronesian and Papuan terms. ${ }^{43}$ We can also identify a strong and continuing focus on ancestral origins and the complex locating of mythic narratives and ancestral itineraries within the Fataluku landscape. Moreover, there is evidently a persistent emphasis on such classificatory binary categories as male/female (nami tupurru), younger/elder (noko kaka), small/large (moko lafae) among numerous other key organising distinctions. The systematic use of ritual speech couplets is also marked, as in the phrases hitu ho coro (sword and spear), ete ho taru (tree and vine), ira ho oco (water and tree crops), iniku ho poku (fine-grained sand and course sand), among others. Seen in these terms, Fataluku society shares much in common with its Austronesian speaking neighbours, both in terms of cultural principles of social order and relation, as well as in the forms of attachment they reproduce in relation to their ancestral lands. As a non-Austronesian-speaking language community with clear evidence that they have borrowed extensively from Austronesian registers and concepts over many generations, their example highlights the limitations of the linguistic distinction-Austronesian/non-Austronesian - to define the scope of cultural comparison in the region. This is not to deny the utility of what may be termed 'Austronesian cultural characteristics'. Rather, as the example of Fataluku and other proximate non-Austronesian-language communities indicates, significant cultural overlap and hybridity offer the prospect for extending comparative analysis beyond the linguistic boundary (see also Platenkamp 1984 and 1988). Recent studies arguing for thematic comparison across this language boundary offer directions for future research (Strathern and Stewart 2000).

While these academic questions are unlikely to trouble policy-makers in East Timor, the more practical issues of integrating Fataluku common property regimes within a park management regime are of central concern. To its credit, the Government appears to have recognised the strong and continuing attachment to and dependency on the diverse resources of the proposed park of local Fataluku communities. Under the present government structure of Timor Leste, the Ministry of Agriculture, Forestry and Fisheries (Ministerio de Agricultura, Floresta e Pesca) has, to date, taken the formal responsibility for park management. An indication of their intentions can be seen in a $2002 \mathrm{draft}$ 'letter of agreement', which seeks to establish a mutually agreed framework for management between the Government and local communities bordering the forest boundaries. Under this agreement, the park will be accorded a 'Category 5 ' status, following the guidelines of the International Union for Conservation of Nature and Natural Resources (IUCN), which establishes the region as a multi-use landscape permitting a range of extractive activities within its 
boundaries. These activities include limited cultivation of fallowed former swidden fields along the park boundary as a temporary concession recognising the impoverished economic circumstances of farmers in the region. Hunting and gathering is to be confined to two months a year with restrictions covering protection of habitat and types of animals available for consumption. Some limited extraction of trees for construction purposes is allowed subject to an agreed permit system. To monitor and coordinate these arrangements, the agreement also envisages the creation of a management commission combining Government and community representatives to promulgate a regulatory framework. Perhaps most significantly, the government offers the possibility of recognising the existence of customary rights in land (tanah adat) as well as sites of cultural importance (tei, lata paru and calu lutur teino) within the park (Surat Kesepakatan 2002, Direccão Geral de Floresta [draft, Bahasa Indonesia version]).

The draft document requires the signatures of the leadership of the three Fataluku villages (suco) bordering the park. ${ }^{44}$ Taken at face value, this agreement represents a realistic understanding of the continuing significance of customary claims and this practical use made of the forest. It also concedes the reality that without active local engagement in the management of the national park, the Directorate of Forestry on its own is ill-equipped to undertake the multiple tasks of managing the region. However, by way of proviso, it is worth noting that the 'letter of agreement' remains in draft form (as of December 2002) and subject to parliamentary and ministerial approval. Until formal ratification of the document and its legal intent is established, the status of the proposed park and the respective rights of individuals, ratu groups and the National Government remains uncertain. The question of the future legal status of customary land (BI: tanah adat) is particularly unclear given that this form of tenure is not recognised explicitly under the East Timorese Constitution, nor has there been any administrative agreement governing the question of customarily claimed land (see Fitzpatrick 2002).

The prospect of recognising a range of customary attachments and interests within the park boundaries is one that needs to be translated into a workable division of respective rights and responsibilities; one that acknowledges the importance of history in policy practice. In the development of a formal regulatory arrangement there would appear to be at least two prospective avenues for government action. Firstly, and perhaps most likely, the National Government will legislate to assume direct ownership of the park and the primary responsibility for management. Arguably, this is consistent with the recently adopted Constitution, which allocates sovereignty over natural resources to the State. Local communities might be encouraged to participate in management, and specific places of heritage significance within the park such as lata paru and ritual sites (calu lutur, ia mari, ete uru ha'a) could be protected under law. ${ }^{45}$ The main difficulty with this approach is the constrained financial capacity of 
the Government to develop its own effective system of management with all the monitoring and protection services it requires. Moreover, the assumption of full government control may give rise to feelings of disenfranchisement among customary rights-holders who will have little interest or legal recourse to maintain the forest as a forest. Economic opportunism and increased exploitation are the likely consequences, if the experience of regional autonomy in Indonesia is any guide (see Potter and Badcock 2001).

An alternative or compromise approach is one that recognises and legally supports the tenurial rights of the customary common property-holders, and accords them a form of collective customary ownership of their ancestral lands within the park, under a broad framework of government supervision. While not without its own set of challenges, many of which could be resolved through greater research and public consultation, the existing Fataluku customary tenure arrangements and understandings within the park arguably represent the only consistent and historically legitimate forms of claim over the forested domain. Recognition of common property rights to the forest, as McKean (2000: 42) and others have argued, gives owners the incentive to husband their resources, to make investments in resource quality and to manage them sustainably and efficiently. Moreover, if legal recognition of Fataluku forest tenures was offered on the basis that the park would then be leased back to the nation for the purposes of managed conservation, the basis for a mutual framework of shared interests could be established. Such an approach offers the possibility of building an effective system of joint or co-management that combines the intimate local knowledge and ancestrally sanctioned attachment of local communities with the authority, technologies and financial assistance of external agencies. It is also one that permits a much stronger role for customary rights-holders in decision-making than if principal control and decision-making resides in the central corridors of national government.

The decision about the locus and distribution of legal rights and responsibilities in relation to the park is likely to emerge in the near future, and it represents a necessary condition for developing an effective management regime, but not a sufficient one. As much of the literature on common property rights and community-based management attests, legal recognition represents only one important aspect in promoting sustainable practices (Ostrom 1990; Gibson et al. 2000). Associated complex issues such as boundary definition, membership status and effective local institutions that have enforceable rules and appropriate dispute-resolution mechanisms are just some of the features that contribute to successful co-management arrangements involving common property regimes (McKean 2000; Kant and Cooke 1999). These and other matters will no doubt form the subject of negotiation and contested development over time. In the interim, this paper has simply sought to highlight something of the 
scope and strength of attachment among specific local Fataluku communities to a region of enduring and wider public interest.

\section{References}

Atkinson, Jane M. and Shelly Errington (eds). 1990. Power and Difference: Gender in island southeast Asia. Stanford: Stanford University Press.

Bellwood, P., J.J. Fox and D. Tryon. 1995. 'The Austronesians in History: Common origins and diverse transformations.' In Peter Bellwood, James J. Fox and Darrell Tryon, The Austronesians: Historical and Comparative Perspectives, Canberra: Department of Anthropology, Comparative Austronesian Studies Project, Research School of Pacific and Asian Studies, The Australian National University. pp. 1-16.

Fairhead, James and Melissa Leach. 1996. Misreading the African Landscape: Society and ecology in a forest savannah mosaic. Cambridge/New York: Cambridge University Press.

Fitzpatrick, Daniel. 2002. Land Claims in East Timor. Canberra: Asia Pacific Press.

Fox, James J. (ed.) 1997. The Poetic Power of Place: Comparative perspectives on Austronesian ideas of locality. Canberra: Research School of Pacific and Asian Studies, The Australian National University.

Fox, James J. and Clifford Sather. 1996. Origins, Ancestry and Alliance: Explorations in Austronesian Ethnography. Canberra: Research School of Pacific and Asian Studies, The Australian National University.

Gibson, Clark C., Margaret A. McKean and Elinor Ostrom. 2000. People and Forests: Communities, Institutions and Governance. Cambridge (Mass.) MIT Press.

Gomes, Francisco de Azevedo. 1972. Os Fataluku. Lisboa: Instituto Superior de Ciencias Socias e Politica Ultramarina, Universidade Tecnica de Lisboa.

Lameiras-Campagnolo, Maria O. 1972. 'Deux enquêtes à Timor Protugais chez les Fataluku de Lórehe.' Asie du sud-est et monde insulienden, 3 (3). pp. 35-52.

Lameiras-Campagnolo, Maria O. 1975. 'L'habitation des Fatuluku de Lórehe (Timor Portugais).' Paris: Thèse de doctorat de 3ème cycle, Université René Descartes, Sorbonne, Paris.

Hull, Geoffrey. 1998. 'The Basic Lexical Affinities of Timor's Austronesian Languages: A Preliminary Investigation.' In Geoffrey Hull and Lance Eccles (eds), Studies in Languages and Cultures of East Timor, Vol. 1, Macarthur (Aust.): Language Acquisition Research Centre, University of Western Sydney. pp. 97-198. 
Hviding, Edvard and Tim Bayliss-Smith. 2000. Islands of Rainforest: Agro-forestry, logging and eco-tourism in Solomon Islands. Aldershot, Burlington, Sydney: Ashgate Publishing.

Kant, Shashi and Roshan Cooke. 1999. 'Jabalapur District, Madhya Pradesh, India: Minimizing conflict in joint forest management.' In Daniel Buckles (ed.), Cultivating Peace: Conflict and Collaboration in Natural Resource Management, Ottawa and Washington DC: International Development Research Centre and the World Bank Institute. pp. 81-97.

Kantor Statistik 1993. Timor Timur Dalam Angka (East Timor in Figures). Government of the Province of East Timor.

McKean, Margaret A. 2000. 'Common Property: What Is It, What It Is and, What Makes It Work.' In C. Clark, M. Gibson, A. McKean and E. Ostrom (eds), People and Forests: Communities, Institutions and Governance, Cambridge (Mass.): MIT Press.

McWilliam, Andrew. 2003. 'Timorese Seascapes: Perspectives on customary marine tenures in East Timor.' The Asia Pacific Journal of Anthropology, 3 (2). pp. 6-32

Ostrom, Elinor. 1990. Governing the Commons: The Evolution of Institutions for Collective Action. Cambridge, New York: Cambridge University Press.

Platenkamp, J.D.M. 1984. 'The Tobelo of Eastern Halmahera in the context of the Field of Anthropological Study.' In P.E. de Josselin de Jong (ed.) Unity in Diversity: Indonesia as a Field of Anthropological Study, Dordrecht-Holland: Foris Publications.

Platenkamp, J.D.M. 1988. 'Tobelo.' Unpublished PhD thesis Leiden University, Leiden.

Potter, Lesley and Simon Badcock. 2001. The effects of Indonesia's decentralisation on forests and estate crops in Riau province: Case studies of the original districts of Kampar and Indragiri Hulu. Bogor (Indonesia): CIFOR, ACIAR, DFID.

Smith, Joyotee and Sara J. Scherr. 2002. Forest Carbon and Local Livelihoods: Assessment of Opportunities and Policy Recommendations. Bogor (Indonesia): Centre for International Forestry Research, Occasional Paper No. 37.

Strathern, Andrew. and Pamela J. Stewart. 2000. The Python's Back: Pathways of Comparison Between Indonesia and Melanesia. Westport (Conn.) Bergin and Garvey.

Whistler, Art. 2000. 'Ecological survey and preliminary botanical inventory of the Tutuala Beach and Jaco Island protected natural areas, East Timor.' Report to the United Nations Transitional Administration in East Timor. 


\section{Vischer, Michael P. (ed.) Forthcoming. Precedence: Processes of social differentiation in the Austronesian World. Canberra: Pandanus Books.}

\section{ENDNOTES}

1 This paper was based on research undertaken in East Timor during 2001 and 2002 with funding from the Australian National University. Acknowledgment is extended to Umberto Rakupua, Arsio da Costa, Mario dos Santos Loyola and staff of the Directorate of Forestry in Timor Leste, Almeida Xavier, Mario Nunes and Fernandu Santana, for their assistance and advice.

2 Exceptions to this general statement include the work of Gomes (1972) and Lameiras-Campagnolo (1972, 1975).

3 The reputed biodiversity, however, is based on very limited biological or botanical inventories of species mix and composition.

4 An area of 25,163 ha was officially classified under this category of protection (Timor Timur Dalam Angka 1993).

5 Bio-exploration refers specifically to the possibility for joint-venture exploration of flora and fauna biological resources in terrestrial and marine sites for prospective commercial applications (Maunsey, pers comm., 2002). Carbon-credit trading is a potentially exciting avenue for supporting forest conservation in East Timor following the agreement of the Clean Development Mechanism of the Kyoto Protocol. But it is one that requires further clarification and development to operationalise (see Smith and Scherr 2002).

6 In the other subdistricts of Iliomar and Luro a range of other languages are used, all non-Austronesian. Macalero is the indigenous language of Iliomar, while in Luro the languages of Macassae and a dialect form known as Sa Ani predominate.

7 Said by some to be a Portuguese transformation of the Fataluku phrase los Pala, meaning, 'fertile garden'.

8 The other TNGP linguistic communities of note are the Bunak in central Timor and Macassae, the dominant language of Baucau, adjacent to Lautem District.

${ }^{9}$ Hull uses this example to support his hypothesis that the 'first Austronesians of Timor may well have been settlers from coastal New Guinea, and of mixed Austronesian and Papuan stock and culturally, but not linguistically Austronesian, (1998: 165).

10 The language of Lovaia (Makwa) is currently restricted to a few speakers in the hamlet of Porlamano in Mehara village near Lake Ira Lalaru. Historical sources suggest the language was spoken much more widely in the past and is likely to have predated Fataluku settlement in this part of Timor.

11 Most of these administrative units were converted to desa (villages) under Indonesian rule but have now reverted to the older term under the new National Government.

12 Many Fataluku names inherited within ratu groups use the (Tetum language) qualifier malae, meaning 'foreign'. For example, the Opo ratu group uses names such as Ke malae (f.), Rusu malae, Pitino malae, Lavanu malae, while Loh Ratu has Iniku malae, Lelunu malae and so on. The use of this very Austronesian qualifier and its reference to external origins is an unusual cultural legacy among this 'indigenous' language community in East Timor. But it is consistent with the pervasive attention to seafaring mythologies of origin and the ancestral settlement of the island.

13 Different ratu are said to possess unique powers and capacities to control natural elements, animals or spirit beings, which practitioners can utilise for protection or retribution (kesino, loconu).

14 Caste is defined here as a rigid system of inherited social distinctions.

15 A further category of people referred to as acaru (sorcerers, witches and shape-changers), who are feared for their malevolent activities. Like other social categories, descendants of acaru are also believed to take on this status.

16 Significant variation in this form is, however, common. Other sites use carved timber posts such as banyan (hama) and ironwood (fara, sauata).

17 These venerated figures were frequently subject to desecration and looting during the period of Indonesian rule, and consequently, many have been moved to locations within or close to present settlements for protection. Ete-uru ha'a can also take alternative forms, including carved wooden sacrificial posts. 
18 The remarkable number of these former fortified settlements, particularly in the forested eastern lowlands and hinterland, is suggestive of a possible significant depopulation of the area in historical times.

19 Aca is a semantically rich term in Fataluku with multiple meanings including 'wood', and as a classifier for 'fowl', but here, the term aca kaka can be translated as 'elder hearth'. The 'sacred hearth' finds similar expression in the language of Tetum as ahi matan, literally, the 'eye of fire', which represents the 'origin hearth' of the affiliated group.

20 See Campagnolo (1975: 77). Sacrificial posts are also known as saka.

21 Ancestral invocations typically begin by calling on the calu ho papu (lit. 'grandfather and great grandfather'). These categories of ancestor represent more the immediate agnatic antecedents of the group; however, Fataluku also recognise two additional levels of male ancestors, cuci ho macua ('FFFF and FFFFF'). These terms also apply reciprocally and symmetrically to descending levels of progeny (grandchildren, great-grandchildren and so on). The names of origin ancestors may not be spoken.

22 The house shrine contains the principal altar post sometimes referred to as sikua lafai (the great sikua). However, householders may also utilise subsidiary sikua protective devices for their crops or livestock. The use of loho sikua at buffalo corrals is a case in point. These protective devices fend off the potentially destructive interests of a variety of spirit beings (ciapu) and witches (acaru) as well as ordinary thieves.

23 Women and young children of the ratu may not eat of the sacrificial meat because of its spiritual heat (timine). Younger daughters of the ratu are explicitly excluded because of their intended incorporation within their future husband's ritual group.

24 Horo is a reference to the widespread stony coralline surface of land in this part of East Timor.

25 Also referred to as the 'lord of the lontar and swidden garden' (tua ocawa, pala ocawa).

26 Fernandu Santana of the Government Forestry Directorate has completed a survey of the proposed park boundaries including the number and extent of ratu claims within the area, which probably involve less than 10 principal groups.

27 Like much of the population of Lautem at this time, they fled to the great mountains of Matebian in the neighbouring district of Baucau, and eked out an existence there until 1979 when the survivors surrendered to the Indonesian military and straggled back to Los Palos.

28 Uses included sturdy timber trees for construction, medicinal trees, edible fungi, fruit and leaves as well as rattan, forest tubers and trees tapped for burnable oils.

29 I am not able to identify this and many other tree species. However, based on matching survey data from preliminary work in the Vero River Valley to the east, commonly identified species include apocynacae, sapotacae, ficus, anacadiaceae, Intsia bijuga (ironwoods), syzigiums and steculiacea. The western Paichao Range is wetter than corresponding forest further east and consequently reflects a range of tree and plant species that are not identified in existing survey data as of 2003.

30 Such trees traditionally may form part of the bride-wealth exchanges offered in the conduct of marriage.

31 The original Muapitine is a forest settlement (lata paru) from where contemporary members of the community were relocated by the Indonesian Government. Mass resettlement of Timorese communities was a continuing feature of Indonesian occupation (see Fitzpatrick 2002: 135).

32 The people of Vero supported the independence struggle despite the torching of their former settlement some distance away by Fretilin in 1978, as part of the campaign to undermine Indonesian claims of military success over the indigenous opposition. Former Falantil leader Konis Santana, from the local ratu group Kukulori, was one of many young Fataluku men of Tutuala who depended on the support of communities such as Vero to sustain their armed struggle.

33 The mooted possibility of reopening a former rain-fed rice area on the Aleara Moko lowlands near the mouth of the Vero River is an example.

34 His rights have devolved from his father, who married into the Kukulori ratu group from Iyoro settlement and gained access to the land.

35 Irinu ete taro on kesi kesi ('forest tree vines still intact').

36 Possibly cognate with the Austronesian term teluk (bay, cove or gulf).

37 The Vekase River also separates the former political domains of Tutuala and Muapitine.

38 Although originally settling with Paiuru ratu, it is said that the status of this group is subsidiary to Renu ratu. Paiuru ratu is referred to as the 'paddler' of the origin boat (Loiasu matar), while Renu ratu 
commandeered the boat. Hence the group may be referred to as Paiuru Tirimana (from paiuru, 'paddle'). They maintain a younger/ elder (noko kaka) relation with Renu ratu.

39 Pai ratu is said to have died out and its lands, centred on the former settlement site (lata paru) of Maiana, have reverted to Rene ratu.

40 Under the former UNTAET Regulation 19/2000, which remains in force, sea turtles are a protected species and their consumption is not permitted. This regulation appears not to have had much effect in this part of East Timor where hunting and consumption of numerous protected species is common.

41 The work of Hviding and Bayliss-Smith (2000) in the Solomon Islands offers an example of the kind of approach and detailed assessment that might be attempted for the proposed park area.

42 As Fox (1997: 8) notes, topogenies take a great variety of forms among Austronesian populations. They may recount the journey of an ancestor, the migration of a group or the transmission of an object.

43 The term tahi is cognate with the common Austronesian term tasi commonly used throughout Timor, which typically also adopts the male/female distinction. This refers on one level to the supposed 'calm' qualities of the Savu Sea to the north and the 'rough' Timor Sea to the south. However, the designation also speaks to a symbolic association of male and female to the east/south and west/north coordinates respectively.

44 I note that the agreement also includes marine areas around Jaco Island and the culturally important freshwater Lake Ira Lalaru, to the north of the Paichao Range. Representatives from Mehara, one of the affected villages (suco), have strong traditional interests covering the lake and its shores.

45 A prospect mooted by the village head (Chefe do Suco) on the basis of what, I assume, were previous discussions with government forestry staff. 